\title{
Knowledge, the Curriculum, and Democratic Education: The Curious Case of School English Abstract
}

Debate over subject curricula is apt to descend into internecine squabbles over which (whose?) curriculum is best. Especially so with school English, because its domain(s) of knowledge have commonly been misunderstood, or, at least, misrepresented in the government's programmes of study. After brief consideration of democratic education (problems of its form and meaning), I turn to issues of knowledge and disciplinarity, outlining two conceptions of knowledge - the one constitutive and phenomenological, the other stipulative and social-realist. Drawing on Michael Young and Johan Muller, I argue that, by social-realist standards of objectivity, school English in England as currently framed in national curriculum documents falls short of the standards of 'powerful knowledge' and of a democratic education conceived as social justice. Having considered knowledge and disciplinarity in broad terms, I consider the curricular case of school English, for it seems to me that the curious position of English in our national curriculum has resulted in a model that is either weakly, perhaps even un-, rooted in the network of academic disciplines that make up English studies.

\section{Knowledge, the Curriculum, and Democratic Education: The Curious Case of School English}

To accept Ansgar Allen and Roy Goddard's claim that education is always 'political in that it is intimately involved with the values and interests that government serves and the social ends it purses' $(2017,6)$ is to presuppose, among other things, that the various forms of state-provided or -sanctioned education tell us something about the state's attitude towards, or conception of, education. ${ }^{1}$ In recent years in England, central government has tightened its control of most curricular aspects of schooling, and so my aim in what follows is to consider issues of democratic education in relation to curriculum design, knowledge, and disciplinarity.

Debate over subject curricula is apt to descend into internecine squabbles over which (or whose?) curriculum is best. Especially so with school English, because its domain(s) of knowledge have commonly been either misunderstood or misrepresented by the government's programmes of study. After briefly outlining why a democratic education that consists in mirroring democratic political machinery and process may not be the only or even the best way of 'doing' democratic education, I turn my attention to issues of knowledge and disciplinarity. Here, I outline two conceptions of knowledge - the one constitutive and phenomenological, the other stipulative and social-realist - and trace a line of continuity between them. Drawing on the work of Michael Young and Johan Muller, I hope to show how and why, by a social-realist standard of objectivity, school English in England as currently framed in national curriculum documents ${ }^{2}$ falls short of the standards of 'powerful knowledge' and of a democratic education conceived as social justice. Curriculum design, and the presuppositions upon which it is based, is as central to the possibility of a democratic education as any democratic mechanism by which a school might operate. Having considered knowledge and disciplinarity in broad terms, I consider the curricular case of school English, for it seems to me that the curious position of English in our national curriculum - its pre-eminence, as the government has it (DfE 2013a: 2; 2014a: 3) - has resulted in a model that is weakly, perhaps even un-, rooted in the network of academic disciplines that make up English studies.

\section{Where and what is the democratic in democratic education?}

To speak of democratic education is no easy thing, for the meaning of the term is hardly self-evident. Dewey (1916), of course, still looms large, his general conception of education's democratic impulse resting on several principal claims or theses: mass education must be a means by which socio-political progress is achieved (education as socio-political progress); the only defensible social project is one that aims for the free interactions of persons within and between societies (intra- and inter-societal comity); an adequate education must 'giv[e] individuals a personal interest in social relationships and control, and the habits of mind which secure social changes without introducing disorder' (socially

\footnotetext{
${ }^{1}$ Education is (always-already) political in other ways too, of course. In the spirit of Judith Butler's gender politics, Deborah Youdell (2011) has examined schooling as a site of person-, or citizen-, making, social in-/ex-clusion and inequality, and as site of radical political resistance.

2 I don't assume that institutions and practitioners teach only to the curriculum, which is, it must be noted, intended as a minimal curriculum. My concern, however, is with the political framing of subject knowledge, not with individual attempts to move beyond or around it. In what follows, I refer to the National Curriculum, to Key Stages, and to academy schools - all particular to English education. Readers unfamiliar with these might begin with the relevant government websites (see References).
} 
rooted personal empowerment) (1916: 99). Educational thinking must have a clear sense (socially, morally, politically, historically) of where We are, how We got here, where We are (ideally, hopefully?) going, and how We are to get there; it must, then, take lessons from the past without aiming merely to reiterate uncritically past values and beliefs, and it must challenge and break from the past where its mores are found wanting. ${ }^{3}$

While he gives few (if any) historical examples, Dewey does recognize, in principle, that educational theorizing and planning must be sensitive to historical contingency. Nevertheless, so broad, and at times abstract, are Dewey's outline of education's democratic impulse and his definition of democracy (as 'a mode of associated living' [1916: 87]) that it is unclear how these are to be realized. The case of Alex Bloom, whom Michael Fielding $(2005 ; 2014)$ has sought to restore to the pantheon of educational figures, exemplifies one form of Deweyan democratic education. In mid-century, post-war Britain, Bloom was head of St. George-in-the-East, Stepney (east London). Bloom used direct- and representative-democratic mechanisms - in the form of various staff-student councils, ranging in size from whole-school down - so that student voice was always at the centre of the school's everyday running and decision-making processes. Here, then, is an example of the school as a truly democratic polity. As Fielding is aware, however, Bloom enjoyed relative autonomy over his relatively small school (and 'size matters,' writes Fielding [2005: n.6]).

Fielding's first piece on Bloom was published in 2005, since when state control over curricula in England's school system has tightened. One might wonder, then, to what extent a school that introduced direct-democratic mechanisms, pace Bloom, while still being bound by current government-led curricula and performance metrics would be meaningfully democratic (or simply more democratic than before). I do not dismiss Fielding's arguments about, for example, the moral and political importance of student voice. I simply want to suggest (a) that the democratic potential of formal education might be realized in ways (including, as we will see, curriculum reform) that neither foreclose nor rely on the implementation of apparently democratic mechanisms; and (b) that the introduction of apparently democratic mechanisms does not in and of itself guarantee the actual democratic functioning of a school. Fielding's example is of a school which was, top to toe, a functioning democratic entity. But it is easy to imagine, in an era of multi-academy trusts and schools with student numbers commonly in the thousands, a school with numerous student-led bodies fulfilling consultative but non-executive functions. Fielding acknowledges that such democratic mechanisms as Bloom used are important only insofar as they are means of realizing positive relationships and encounters with others, for these are, he believes, 'both the end and the means of our fulfilment' (2005: 131). And he also speculates that the various bodies enabling student voices at St. George-inthe-East were a far cry from 'the now frequently encountered tokenistic enclave in which some student voices talk to each other without much evidence that staff, or indeed other students, know very much or care very much about what was said and what did or did not happen as a result' (2005: 126). Certainly, it is also easy to imagine that certain student positions and voices might be easily silenced by the introduction of apparently democratic mechanisms: any group, which coheres around a shared mode of identity and/or identification, ${ }^{4}$ might find itself, by virtue of being a statistical minority, unrepresented and effectively voiceless on some elected student council. Fielding recognizes that '[o]rganisational arrangements, democratic or otherwise, are a necessary, but not a sufficient condition of our wellbeing together' (2005: 131). Apparently democratic mechanisms and functioning, then, while not to be dismissed, are no guarantee of a meaningfully democratic education (at least as Dewey imagined it).

\section{Knowledge and the Curriculum}

Let's turn now to the issue of curriculum design as a site of educational in-/equity, and thus of educational democratic potential. A critique of curriculum design must pay attention to questions of knowledge, for, according to some received views, it is precisely knowledge that is at stake in formal education. One reference work will suggest that " $[$ t]he first parental answer given to the child's question, "Why should I go to school?", is to say "To acquire knowledge," although there is much to say after that' (Inglis and Aers 2008: 114). There is indeed much to say, for, as another entry on knowledge points out, if knowledge-acquisition - whatever we are to make of that term - is for many 'a non-negotiable demand,' then 'the delineation of the scope and limits of knowledge must be central concerns for any theory of education' (Winch and Gingell 1999: 125).

In recent years, educational debate in England's public-political arena has been framed as a battle for knowledge, for its restoration to the centre of the educational mission. Repeatedly, argument is framed as a

\footnotetext{
3 As a case in point, Dewey's chapter in Democracy and Education on the 'democratic conception in education' draws critically, but not dismissively, upon Platonic, Romantic, and Victorian educational formulations.

${ }^{4}$ On the 'structure of social identities,' see Appiah (2005: 65-71).
} 
competition between knowledge (a 'knowledge-rich' or '-centred' education) and skills, and there has been surprisingly little challenge to the placing of these terms in opposition; indeed, the contrast between knowledge and skills seems now to be part of received wisdom. England's curricular reforms of 2015 were presented as a knowledge-centred corrective to a generation of 'empty' skills-based schooling. Where critics of liberal-progressive education have sought to be charitable, the knowledge/skills diremption is presented as a 'false dichotomy,' but one which is nevertheless solved - or dissolved - through (re-)establishing the primacy of knowledge. ${ }^{5}$ Thus, the argument runs contradictorily: there is no opposition between knowledge and skills; both are necessary. However, some things are more necessary than others. Knowledge first; skill can follow. Where some have sought to defend, implicitly or explicitly, skills over and above or as equal to knowledge, the tendency has been to accept the opposition and simply flip the privileged term. ${ }^{6}$ And even where knowledge and skills are not invoked in opposition to one another, they are still presented as distinct, though just how this is so is generally unclear as, usually, neither term is defined. ${ }^{7}$ (Of this latter case, one is tempted to say, so commonly collocated are 'knowledge' and 'skills,' that the phrase 'knowledge and skills' manages to fudge the difference between knowledge-or-skills and knowledge-as-skills.)

Two accounts of knowledge require our consideration: the first, constitutive, consists of attempts to say what knowledge is, how it is structured, what are its grounds of possibility. Such accounts may be ontologicalphenomenological or epistemological, though in the most convincing accounts epistemology shades into ontology, as the grounds of knowing are the knower. Robert Brandom's inferentialism, for example, does not do away with apparently intellectualist terms like reason and rationality; but these are, for Brandom, practical or pragmatic matters (1994; 2000). His approach implies, at the personal level, an embodied, corporeal person, even though he doesn't focus primarily on the body. The second approach is a stipulative project: here, just what knowledge is might be taken for granted; the question to be considered is What do persons need to know and why?

Constitutive accounts of knowledge will often have recourse to Ryle's summary of the knowledgethat/know-how $(\mathrm{KT} / \mathrm{KH})$ problem (Ryle 1949), which provides either a conceptual starting-point or framework for discussions of practical and theoretical knowledge, academic and vocational education, tacit and explicit (or codifiable) knowledge. Constitutive accounts also imply, if they do not directly address, issues of embodiment and embodied knowledge (to what extent is embodied knowledge practical and/or tacit, as opposed to theoretical and/or explicit?), and the at times acroamatic arguments over the possibility or utility of non-conceptual knowledge. ${ }^{8}$ As space is limited, I will re-state, rather than argue for, my position. ${ }^{9}$

At the personal level, all knowledge is embodied, in that it necessarily presupposes a flesh-and-blood knower. There are no knowledgeable acts that cannot be adequately understood in terms of (more or less) skilled performance, though this does not do away with or simply ignore the possibility of ratiocination, theorizing, and so on; it merely takes the flesh-and-blood person (rather than propositional knowledge or 'content,' thought of as some kind of executor) as the enabling ground for such acts, and understands ratiocination and theorizing as practical activities. The primacy of the body, or the embodied person, is a central feature of post-Heideggerian phenomenology; it shapes the work of Merleau-Ponty and Sartre, and others working in the main stream, margins, and beyond the bounds of academic philosophy. ${ }^{10}$

If this outlines, however briefly and broadly, a constitutive account of knowledge (as embodied) at the personal level, then what of shared or social knowledge? An important question, this, for if one aim of education is that students gain knowledge, then what is gained must be knowledge of something, and it must surely also be knowledge that is - at least, some knowledge ought to be - valid for everyone, transcendent (Bonnett 1995), and offers some sort of purchase on the world. It is enough, for our purposes, to say with Brandom (2000) that shared or common knowledge is socially constituted, involving consensus and recognition among those positioned as, to borrow from Lorraine Code (1991), 'epistemology makers.' Recognizing the socially constituted nature of (shared/common) knowledge does not entail frictionless relativism or pluralism, however, nor does it do away with

\footnotetext{
${ }^{5}$ E.g. Christodoulou (2014). In Gove (2013b), 'skills' (used four times) is sometimes used in reference to the capacities of good teachers, while 'knowledge' (used twenty-four times) is the end of education. Gibb (2016; 2017) tends explicitly to oppose knowledge and skills, favouring the former, as does Christodoulou.

${ }^{6}$ E.g. Schrage (2010), CBI (2018; n.d.). For a more nuanced debate over generic thinking skills and issues of knowledge/content, see Bonnett (1995), Hinchliffe (2002), Higgins and Baumfield (1998) and the response of Johnson and Gardner (1999).

${ }^{7}$ See, again, CBI (2018; n.d.); Gove (2014).

8 See, for example, Dreyfus (2013) and McDowell (2013).

${ }^{9} \mathrm{I}$ have spelled out the arguments for my position in [self-identifying references].

${ }^{10}$ See, for example, Dreyfus (2013; 2014), McDowell 1994; 2013), and their argument over the possibility of non-conceptual knowledge (Schear 2013); Brandom's pragmatism-inflected inferentialism (1994; 2000); Butler (1999); Gordon (1997); Yancy (2017); Maracle (1996); DuBois (1903); Baldwin (1998).
} 
objectivity. It simply recognizes the contextual and contingent nature of knowledge production, the always-in-principle fallibility of knowledge and thus, without repudiating it, of objectivity. Knowledge-production is contingent, but this does not mean that knowledge itself is constrained to its moment of birth. There are things that can be known; but the ways and terms in which we know them are subject to revision and improvement. ${ }^{11}$

It will be obvious to some readers that the constitutive account I favour is in keeping with social realist perspectives on knowledge. Socialist realism points a way from the constitutive to the stipulative - from, that is, questions of what knowledge is to what knowledge 'matters,' or, in this case, what knowledge should be taught. Not all stipulative accounts, of course, are social realist (see n.5). The constitutive argument from embodiment rejects attempts (such as those outlined above) to divide forms of understanding into knowledge and skills: it takes knowledge per se as embodied capability, and thus considers those arguments pressing knowledge over skills as little more than arguments over preferred curricular content. Such questions as what should be taught?, what should be on the curriculum? are important; this much is not disputed. But curricular preference cannot be legitimized by an appeal to knowledge over and above skill - or, indeed, vice versa - as such arguments collapse under the weight of their own incoherence. They fail, first and foremost, to understand just what knowledge is (or, rather, what are its conditions of possibility).

By contrast, Michael Young's 'powerful knowledge' (PK) offers a stipulative framework that is social realist. PK has not been without controversy, but, as Young and Johan Muller have been at pains to explain, 'powerful knowledge' does not equate to 'knowledge of the powerful' (2013: 233). Specialization and disciplinarity are central to PK, for what sets it apart from other domains or forms of knowledge is that it must be taught: it cannot (as the saying goes) be caught; it is not commonsense, intuitive; it will always have a disciplinary and traditional-institutional element. ${ }^{12}$ All PK, then, is specialized knowledge, but the same is not true vice versa (Young and Muller offer scientology as an example of specialized, but not powerful, knowledge [2013: 231]). It is, Young and Muller contend, only through increased specialization that knowledge - ways of knowing - can be improved (ibid.). PK, as a species of specialized knowledge, may be manifested in various and varying ways, but, as Young and Muller describe it, it has four common properties (2013: 236-38): it is (i) systematically revisable, (ii) emergent (socially produced, but not reducible or only applicable to this social context), (iii) real (it has genuine purchase on, or explanatory power of, some aspect(s) of the world), and (iv) is both material and social (a social-realist phenomenon, constitutive of disciplinarity). In many ways, (iii) and (iv) are species of (i) and (ii). PK, then, is systematic and revisable; that is, in keeping with Cassirer, Kuhn, Taylor, and others, it aims for real explanatory power, for the best possible account, and, as such, is always in principle fallible. This necessitates that it is sociohistorically produced but not constrained (the property of emergence), and will, in any given domain of PK, develop its own criterial norms of acceptability or validity (pace Brandom 2000).

What sets PK apart from many non-social-realist stipulative accounts, then, is the way in which the value of (powerful) knowledge is conceptualized. Whereas non-social-realist stipulative accounts take knowledge as either or both culturally more valuable and logically prior to skills, PK does not have

a higher cultural value than non-specialised knowledge. Specialisation is not a basis for denying respect or value to non-specialist common sense knowledge that people draw on in their daily lives. Specialist knowledge is 'powerless' in enabling someone to find their way about a house or city with which they are unfamiliar or helping a friend who has lost a child. The difference between specialised and non-specialised knowledge is a difference of purpose and [...] a difference of structure; it is not a difference of value, except in relation to those purposes. (Young and Muller 2013: 231)

Starting with PK, then, we can add an instructive gloss to the apparent truism that the purpose of schooling is to teach knowledge: the purpose of formal education (mass schooling) is the teaching of those forms of specialist and/or powerful knowledge that can be neither taught nor caught (as efficiently, if at all) outside of some educational or training institution. Notice the continuity between the constitutive account of knowledge I favour and PK: specialization begins to bridge - more precisely, to render pointless - the received gap between knowledge and skill, because, from the perspective of PK, the purpose of schooling is surely to induct students into various ways of being - how-to-be a scientist, historian, mathematician, athlete, and so on.

\footnotetext{
${ }^{11}$ Brandom (1994; 2000), as I have suggested, offers one such account, and his work has been drawn upon in recent years by several philosophers of education.

${ }^{12}$ This is not to say, however, that disciplinary and 'everyday' knowledge do not exert pressures on, or interanimate, one another. See Zipin's Vygotsky-influenced account (2017).
} 


\section{The Arts and English Studies}

Young and Muller subscribe to a view of knowledge that is, all the way through, 'socio-epistemic' (2013: 244). All knowledge domains are subject to rational processes, and are bound by criterial norms, standards of right and wrong and objectivity; but it is the 'disciplinary community' that governs the epistemic. This applies as much to the social as natural sciences. The weaker or stronger the disciplinary community, the weaker or stronger the domain of knowledge as specialized - and thus powerful - knowledge (ibid.). But once the opposition of 'natural' to 'social'/ 'cultural' kinds morphs into the received opposition of the rational and non-rational, the social sciences - and by extension the arts - are easily misunderstood as domains of non-specialized, non-powerful, 'soft' or 'folk' knowledge (ibid.). Young and Muller aim to show that the arts, as much as the social and natural sciences, operate within the economy of PK. To do this, they must show that artistic knowledge shares PK's four common properties:

What distinguishes arts from the sciences and social sciences is that although they are specialised and subject to the constraints and the boundaries associated with other types of specialised knowledge, they are not exclusive to specialist practitioners. You do not need to play the violin to appreciate Mozart, to write a novel to have read Jane Austen, or to be able to dance to enjoy the Bolshoi Ballet. In each case though it is possible to gain a kind of freedom from everyday melodies, texts and movements, and to imagine an enhanced set of possibilities in each of those domains.

Whereas the sciences speak to the particular from the general, the arts speak to the universal in the particular, and can enable people to feel part of a larger humanity. [...] What distinguishes the arts from other forms of 'powerful knowledge' is that although they have conventions, they are explicitly licensed to violate them, 'to entertain, to surprise, to outrage, to be original'. This [...] is their inherent subversiveness and why political regimes, especially dictatorial ones, try periodically to repress them.

There is one important similarity with other forms of 'powerful' knowledge that we have discussed. It is that the conventions (or boundaries) of the discipline, for arts and sciences alike, provide the conditions for being able to transcend them. This returns to our initial definition of 'powerful knowledge' - that it is specialised and differentiated from everyday thinking. At the same time we have extended the meaning and range of 'power' from the more obvious predictive powers of the STEM subjects to those subjects and disciplines that are rarely sources of generalisation or prediction but sources of the power to 'shock, outrage, and surprise' and hence transcend the limits in every present. That surely has to be part of any curriculum entitlement. (2013: 246)

While it is true that one does not have to be an instrumentalist to be moved by a piece of music, it is also obviously though not unimportantly true that the expert violinist and non-musician will, in very real ways (property [iii] of PK), hear different pieces of music, though they sit through the 'same' performance of the 'same' symphony. There are no good grounds for gainsaying individual responses to artworks; but the musician will have access to a way of knowing that is inaccessible to the non-musician; moreover, the articulate musician may well be able to explicate their knowledge of the symphony to the non-musician in terms to which the non-musician would not (previously or otherwise) have had access. The same can be said for expert and non-expert responses to boxing, weightlifting, acting, and so on. There is no guarantee of consensus among musicians over a piece or performance, just as there is no guarantee of consensus among sporting pundits over this or that contest. But neither is there any guarantee of consensus among scientists on all aspects of science - not least because what we call science is a complicated network of many sub-disciplines (which tend to produce perspectival biases ${ }^{13}$ ), and because of the speculative nature of paradigmatic, rather than normal, science. ${ }^{14}$ Thus, Young and Muller's point about exclusivity/inclusivity is misplaced: simply put, it doesn't do much work. According to the 'rules' governing PK, all domains are open to specialist and non-specialist appreciation; but specialists will always have a certain purchase on phenomena that nonspecialists, by definition, will not.

Part of the apparent problem of knowledge with respect to the arts, as Young and Muller present it, lies in the assumption that in arts education we are training persons to be spectator-consumers rather than producerparticipants. I do not mean to suggest by this that the choice is necessarily either/or - spectator or producer. In literature studies, reader-response theory has, for several decades, offered powerful arguments for recognizing readers as meaning-makers. ${ }^{15}$ My concern, however, is that students are not adequately positioned as meaningmakers, and, indeed, that expression and meaning-making are not sufficiently foregrounded, in the current frameworks for English study. Such issues, I would suggest, do not arise in quite the same way in mathematics or

\footnotetext{
13 See, for example, Rose (1997) on epistemic pluralism.

14 This is strikingly dramatized in the documentary film Particle Fever (Levinson 2013).

15 See Tompkins (1980); one might also turn to Rancière (2009) and his notion of the emancipated spectator.
} 
the sciences, for example, for we do not in general teach students - though a serious case might be made for asking why not? ? $^{16}$ - to appreciate the elegance or beauty of this or that theorem or equation. Not all students will become mathematicians or scientists in the PK sense of the term; but we do ask that they aim or play at or take on such a being while they are in maths classes. Such is not the case with English, however:

English has a pre-eminent place in education and in society. A high-quality education in English will teach pupils to speak and write fluently so that they can communicate their ideas and emotions to others and through their reading and listening, others can communicate with them. Through reading in particular, pupils have a chance to develop culturally, emotionally, intellectually, socially and spiritually. Literature, especially, plays a key role in such development. Reading also enables pupils both to acquire knowledge and to build on what they already know. All the skills of language are essential to participating fully as a member of society; pupils, therefore, who do not learn to speak, read and write fluently and confidently are effectively disenfranchised.

This comes from the government statement of the 'purpose of study' of English, and appears in the programmes of study for English at Key Stages 3 and 4. The following paragraph is the equivalent in the Key Stage 3 Science document:

A high-quality science education provides the foundations for understanding the world through the specific disciplines of biology, chemistry and physics. Science has changed our lives and is vital to the world's future prosperity, and all pupils should be taught essential aspects of the knowledge, methods, processes and uses of science. Through building up a body of key foundational knowledge and concepts, pupils should be encouraged to recognise the power of rational explanation and develop a sense of excitement and curiosity about natural phenomena. They should be encouraged to understand how science can be used to explain what is occurring, predict how things will behave, and analyse causes.

Interestingly, the above paragraph is not reproduced in the programme of study for Science at Key Stage 4. Instead, it is stated in the introduction that

[t]eaching in the sciences in key stage 4 continues with the process of building upon and deepening scientific knowledge and the understanding of ideas developed in earlier key stages in the subject disciplines of biology, chemistry and physics.

For some students, studying the sciences in key stage 4 provides the platform for more advanced studies, establishing the basis for a wide range of careers. For others, it will be their last formal study of subjects that provide the foundations for understanding the natural world and will enhance their lives in an increasingly technological society.

There is far more to be said about these statements than space allows. Notice, though, how closely the science statements can be mapped to Young and Muller's PK. Science is presented explicitly as a cluster of 'specific' or 'subject' 'disciplines.' With English, things are rather more muddled. English is both culturally valuable ('preeminent') and socio-politically (functionally) necessary. There is little, if anything, of the disciplinary, the specialized here; neither linguistic nor literary knowledge or expertise feature in these paragraphs, as they do in the science statements, nor anywhere else in the documents. ${ }^{17}$ Indeed, the fact that reading is said to 'enabl[e] pupils both to acquire knowledge and to build on what they already know' shifts the purpose of study from English (as a subject or discipline) to functional literacy, to language as a cross-disciplinary bearer of information and trans-domain capacity. Mention of spiritual, emotional, cultural development might be read as a diluted version of Young and Muller's belief in the subversiveness of the arts, if we take both statements as pointing to the arts as transformative rather than informative. But the government document does not state such development in terms consistent with PK. Here, English is precisely a means to other forms of non-domain specific and non-powerful knowledge. Crucially, characterizing reading as a means of conveying information casts it implicitly as a passive or receptive undertaking.

\footnotetext{
16 See, for example, Farmelo (2002).

${ }^{17}$ At the time of writing, a debate is emerging around the disciplinarity of English and its possible erasure in (by?) government policy and curriculum frameworks. See Bleiman (2018), McCallum (2019); see also Eaglestone (2019).
} 
Here, then, when one reads, one is not inhabiting any particular way or mode of being which, I have suggested, is essential to PK (and written into the constitutive account of knowledge I've outlined).

In both the government's programmes of study and Young and Muller, students of the arts are positioned as consumers, receivers, spectators. It is this positioning that enables or encourages the mistaken conclusion that the arts are less specialist, in the PK sense, than the sciences (social and natural). The underlying assumption is that arts education does not (necessarily) induct students into the way-of-being-of an artist. Robert Eaglestone states the problem thus:

Teaching and learning a subject involves more than knowing about a list of texts, equations or processes: it teaches ways of thinking and approaching material, it teaches habits of mind. Because of this, a discipline also teaches an identity, a way to be. [...] But what do we teach our students in English to be when we teach them literature? Possibly not 'Englishers'[.] (2016: 4)

One of the principle problems with the framing of school English (as in, for example, the government's programmes of study) is that it fails to understand what literary criticism is and therefore what we are doing when we do it and why. That is, the forms of active and specialist reading that constitute literary criticism are not adequately distinguished from the seemingly more passive modes of reading (as reception of information). The typical form of English education and assessment - the (critical) essay - is derived from the tradition of literary criticism, and yet there is little of the genuinely literary-critical tradition written into the English curriculum. As I have argued elsewhere ([self-identifying reference]), the essay appears all too often to be the 'natural' by-product of assessment in English, the means by which comprehension and appreciation of texts can be adjudicated, but not as a writerly mode with its own history and traditions. It is the default - and thus apparently, but only apparently, 'natural' - mode of school English. Yet the history of literary of criticism indicates a far more creative, constructive, agential activity: it is, on some accounts, part of an attempt to constellate a cultural history and identity (the articulation, say, of a distinctive national identity, articulated though literary-cultural heritage) ${ }^{18}$ on others, it is a means by which we may explicate both the particular nature of aesthetic experiences, and evaluate between them. ${ }^{19}$ The idea that you do not need to be a specialist practitioner to appreciate the arts is, then, doubly redundant, not only for the reasons I've already offered, but also because one's being transformed through aesthetic experience - and, crucially, being able to recognize and explicate one's transformation ${ }^{20}$ - relies on an openness to those experiences that is more than mere pleasure-in-the-moment; it is a comportment of oneself in relation to the experience that is itself part of the way-ofbeing-of the artist and, indeed, of the critic. ${ }^{21}$ But this is no different to the comportment of the would-be scientist: merely attending a scientific lecture does not make one a scientist, just as merely enjoying a concert does not make one a musician.

The knowledge gained from English may seem at once less disciplinary and more contingent than that learned, say, in a physics class (there are no left-wing electrons or jealous neutrons). But this is only seemingly the case, because we do not position students of mathematics and the sciences - or, indeed, of performing and expressive arts - as spectators as we do English students. Because we do tend to position English students as recipients, stipulative accounts of English can quickly descend into arguments over literary taste that are based precisely on non-disciplinary 'common' knowledge of the sort Young and Muller attempt to guard against. ${ }^{22}$

Although Young and Muller's account of PK is very far from the reformist politics of knowledge underpinning current policy in England, what they might have in common - based on Young and Muller's examples of Mozart, Austen, the Bolshoi - is a received, unexamined belief in the objectivity of aesthetic value. On the principles of PK, however, if one is to study a curriculum of 'great works' of literature, then one needs also to study the values and processes by which those works are established as great (philosophy and history, say, of aesthetics). Likewise, if the rationale behind a literature curriculum is historical importance (apart from our valuations of their literary merit, the argument might go, these writers have shaped the course of English literature), one must study not only the literary texts but also the history of their reception - not as mere 'additional' context, a sort of propositional

\footnotetext{
18 See Hutchinson (1995) on this in relation to the Harlem Renaissance. See also Locke (1925); Reising (1986).

19 This is Richards's (1924) position, whose emphasis on aesthetic experience suggests a link to Dewey (1934; 1938).

20 This moves us from the Aristotelian cathartic model to something closer to Maxine Greene's notion of aesthetic education.

${ }^{21}$ Despite n.12, it is this ontological aspect that is sometimes missing from Maxine Greene, who, ironically, writes in precisely this mode of being-as-artist on the subject of aesthetic experience.

22 Take, example, the presumptions underlying this from Gove (2013a): 'You come home to find your 17-year-old daughter engrossed in a book. Which would delight you more - if it were Twilight or Middlemarch?'
} 
bolt-on, but as central to the texts' meaning(s). One might argue, for example, that it is now impossible to understand Conrad's Heart of Darkness (1899) without understanding something of the historical and biographical circumstances that made it possible, nor without knowing something of its critical reception. One needs, that is, to be inducted into the disciplinarity of literary scholarship.

If, that is, we accept that English as a version of literary criticism is the best version of literature studies going.

Part of the so-called problem that Young and Muller seek to resolve is, of course, how the arts can be brought into the fold of PK on the same basis as the sciences (natural and social). They need, then, some analogy or parallelism between the relationships of science and (in our case) literature students to their disciplines. On the basis, then, of PK as a way of understanding the importance of scientific knowledge and science education, we're bound to conclude that we've got school English all wrong. Its default mode should be the production of literary texts, because to undertake this is surely to inhabit the way-of-being of the writer and her work, just as we ask science students to inhabit the ways of being of scientists. To ask students of literature to write is to position them in ways analogous to that of science and mathematics students when we ask them to 'do' science and mathematics. This shift in emphasis does not entail the removal of critical writing; but it does entail a shift in understanding what critical writing is and what it is for, a shift that would understand critical writing as itself a form or mode of poetics, one parasitic on, thus coming after, so-called 'literary' works. To suggest that school English might need to be rethought so that its students are asked to inhabit the way-of-being of a writer is to bring the argument back to the constitutive account of knowledge-as-embodiment, for this much is presupposed by the idea that in teaching disciplinary knowledge we ask students to take on certain embodied ways of being.

\section{Conclusion}

I have tried to show that a phenomenological-constitutive conception of knowledge may be quite consistent with a social-realist stipulative conception. I have argued, too, that the assumptions underlying the government's stated purpose of the study of English at Key Stages 3 and 4 fail the tests of PK, in large part because the argument for functional literacy skills is not an argument for a PK conception of English. This is not to deny the democratic necessity of functional literacy. But functional literacy is not disciplinary English. And the argument for social, moral, spiritual development cannot stand with a primary emphasis on reading (understood, as appears to be the case, as reception only, and not the making, of meaning), unless one thinks that the aims and end of identity formation is primarily the passive identification with other subject positions, and not also the active articulation of one's own sense of self. There is, by now, an established tradition of literary-theoretical work that aims to think identity through literature while enacting the very operations it describes, and which presents literature as enactive, performative, disclosive. ${ }^{23}$ If my arguments stand, then my claims also lead to the conclusion that Dewey's demand that a democratic education must enable socially enmeshed personal empowerment cannot be realized if the standards of powerful knowledge are not, too. For, as Young and Muller put it, 'Only if you do not think there is "better knowledge" that all have a right to would the principle of social justice reject the entitlement to specialised powerful knowledge through the curriculum' (2013: 231).

This claim seems to me broadly right, though Lew Zipin (2017) raises an interesting objection to PK on the grounds of social justice, the very grounds that Young and Muller claim for PK. The strict partitioning of disciplinary and everyday knowledge should be challenged, argues Zipin, because, in fact, they exist in mutually enriching relation to one another. Zipin sees PK as failing certain tests of democracy and social justice, for it remains insensitive to socio-cultural difference and thus cannot contribute to the redistribution of knowledge among all citizens.

How, then, to conclude?

First, consider whether we need choose between PK, as articulated by Young and Muller, and Zippin, who promulgates instead a 'problematic-based curriculum approach' which takes for granted the cultural contingency of epistemes. Zipin's focus is the nature of curriculum design at the national (or equivalent) level; Young and Muller's the subject level. So while Zipin does not wish to suggest that everyday experience be used instrumentally, simply as a launch-pad for 'properly' disciplinary enquiry (start with a familiar case; move to the general, the abstract, the universal), his argument does not entail that we teach, say, the structure and behaviour of electrons as culturally contingent facts. Zippin is arguing that curriculum design take into account, and make selections based on, certain

${ }^{23}$ For example, Butler (1999), Deleuze (1997), Derrida (1992), Heidegger (1975), Lorde (2007), Merleau-Ponty (1973), among others. 
local, cultural exigencies; but he is surely not suggesting that what be taught not pass the tests of PK. It is not hard to imagine - indeed, it would not be hard to find 'real-life' examples - of an English curriculum that satisfied the demands of both Zipin and PK; one which maintained a strong disciplinary sense of what it is to study literature, and which selected texts based on a Zipin-like cultural problematic. Zipin's approach can accommodate much, if not all, of PK's principles (no one ever said that building subject curricula around PK necessitated teaching all that counts as PK within that subject! How could this ever be achieved, given the dynamic nature of specialist subject knowledge?). As for PK, it is, perhaps, less opposed to Zipin than it is simply uninterested (or unaware).

I have argued that what is needed in England is a conception of and curriculum for school English that satisfies the demands of PK - this in order to retain a sense of the disciplinarity of English, which, once established, all students should have access to as a matter of social justice. But I have also suggested - perhaps recklessly or even mischievously, some might think - that in order to achieve this, school English would need to be re-centred around some model of what is commonly called creative writing. (Students must, I have urged, be offered the opportunity to inhabit the way-of-being of the writer, including that of the writer of literary criticism). Some readers will know that in England there was a short-lived secondary qualification in Creative Writing. Following the discontinuation of the course in 2018, an alternative qualification was set up by a group of teachers and writers who hoped to keep the subject alive in secondary schools. ${ }^{24}$ In September 2018, five of the seven schools listed as offering the qualification were independent (fee-paying) (UCAS 2018). This, of course, is hardly a representative empirical survey; but consider that fact alongside the findings of a recent study which found working-class persons underrepresented in creative and arts industries; and consider that alongside recent moves by Penguin Random House - and the very public reactions against them from the likes of Lionel Shriver - to field employees and writers from a wider range of identitarian backgrounds. ${ }^{25}$ One might conclude, pace Zipin, that access to - or the distribution of - creative arts education is not, in England, equal (just as access to education in general is not). Whether one argues from the perspective of PK or Zipin or both, a good deal of redistributive work surely has to be done.

In the spirit of PK, then, we have an argument for reconceptualising the disciplinarity of school English that cannot, according to Young and Muller, be decoupled from issues of social justice. And we have, too, an argument, in concert with Zipin, for a reframing of English - at the disciplinary and curricular levels; as a creative arts subject if one is bothered by such designations - as an issue of redistributive justice. Here we are not without further conceptual trouble, however, as Creative Writing in England has only recently staked out its own claims to specialism and distinctness - to, that is, itself as a form of powerful knowledge, distinct from English and certainly not its scion (QAA 2016). But that, as we say, is another story.

\section{References}

Allen, A., and Goddard, R. (2017) Education and Philosophy: An Introduction. London: SAGE.

Appiah, K.A. (2005) The Ethics of Identity. Princeton: Princeton University Press.

Baldwin, J. (1998) Collected Essays. New York: Penguin Random House

Belas (2018) 'The Educational Implications of Lionel Shriver's Attack on Diversity “Quotas”.' Available online at: https://www.bera.ac.uk/blog/the-educational-implications-of-lionel-shrivers-attack-on-diversity-quotas (accessed 29 January 2019).

Bleiman, B. (2019) 'Literature: The Walk, Not the Map.' EMC. Available online at: https://www.englishandmedia.co.uk/blog/literature-the-walk-not-the-map (accessed 29 January 2019).

Bonnett, M. (1995) 'Teaching Thinking, and the Sanctity of Content,' Journal of Philosophy of Education 29(3), pp. 295309.

Brandom, R. (1994) Making it Explicit: Reasoning, Representing, and Discursive Commitment. Cambridge, MA: Harvard, University Press.

--- (2000) Articulating Reasons: An Introduction to Inferentialism. Cambridge, MA: Harvard University Press.

Brook, O., O’Brien, D., and Taylor, M. (2018) Panic! Social Class, Taste and Inequalities in the Creative Industries. Create. Available online at: http://createlondon.org/wp-content/uploads/2018/04/Panic-Social-Class-Taste-andInequalities-in-the-Creative-Industries1.pdf (accessed 29 January 2019).

Brown, M. (2018) 'Arts Industry Report Asks: Where are all the Working-Class People?’ Guardian. 16 April.

\footnotetext{
${ }^{24}$ There is no space to re-tell the story of the premature discontinuation of A Level Creative Writing. See, however, WEB (n.d.) and [self-identifying references].

${ }^{25}$ See Brown (2018); Brook, O’Brien, and Taylor (2018); PRH (n.d.); Belas (2018); Flood (2018).
} 
Available online at: https://www.theguardian.com/culture/2018/apr/16/arts-industry-report-asks-whereare-all-the-working-class-people (accessed 29 January 2019).

Butler, J. (1999) Gender Trouble: Feminism and the Subversion of Identity. New York: Routledge.

CBI (n.d.) 'CBI Skills Framework.' Available online at: http://www.cbi.org.uk/cbi-prod/assets/File/pdf/cbi-skills-framework.pdf (accessed 25 November 2018).

--- (2018) Educating for the Modern World: CBI/Pearson Education and Skills Annual Report. CBI/Pearson. Available online at: http://www.cbi.org.uk/index.cfm/ api/render/file/?method=inline\&fileID=12087B3C-FD5F497B-908E5285EA942928 (accessed 25 November 2018).

Christodoulou, D. (2014) The Seven Myths about Education. Abingdon: Routledge.

Code, L. (1991) What Can She Know? Feminist Theory and the Construction of Knowledge. Ithaca: Cornell University Press.

Conrad, J. [1899] Heart of Darkness. Norton Critical Edition, $4^{\text {th }}$ Ed. New York: Norton, 2006.

Deleuze, G. (1997) 'Literature and Life.' Trans. Daniel W. Smith and Michael A. Greco. Critical Inquiry. 22(3). 225230.

Derrida, J. (1992) Acts of Literature. Ed. Derek Attridge. London: Routledge.

Dewey, J. [1916] Democracy and Education: An Introduction to the Pbilosophy of Education. New York: The Free Press, 1997.

--- [1934] Art as Experience. New York: Perigee, 1980.

--- [1938.] Experience and Education. New York: Touchstone-Simon and Schuster, 1997.

DfE (2013a) English Programmes of Study: Key Stage 3 National Curriculum in England. Available online at: https://assets.publishing.service.gov.uk/government/uploads/system/uploads/attachment data/file/244 215/SECONDARY national curriculum - English2.pdf (accessed 03 June 2018).

DfE (2013b) Science Programmes of Study: Key Stage 3 National Curriculum in England. Available online at: https://assets.publishing.service.gov.uk/government/uploads/system/uploads/attachment data/file/335 174/SECONDARY national curriculum - Science 220714.pdf (accessed 26 November 2018).

--- (2014a) English Programmes of Study: Key Stage 4 National Curriculum in England. Available online at: https://assets.publishing.service.gov.uk/government/uploads/system/uploads/attachment data/file/331 877/KS4 English PoS FINAL 170714.pdf (accessed 03 June 2018).

--- (2014b) Science Programmes of Study: Key Stage 4 National Curriculum in England. Available online at: https://assets.publishing.service.gov.uk/government/uploads/system/uploads/attachment data/file/381 380/Science KS4 PoS 7 November 2014.pdf (accessed 25 November 2018).

Dreyfus (2013) 'The Myth of the Pervasiveness of the Mental,' in Schear (2013), pp. 15-40.

--- (2014) Skillful Coping: Essays on the Phenomenology of Everyday Perception and Action. Ed. Mark A. Wrathall. Oxford: Oxford University Press.

DuBois, W.E.B. [1903] The Souls of Black Folk. Oxford: Oxford University Press, 2007.

Eaglestone, R. (2016) 'What Do We Teach When We Teach Literature?' The Use of English 67(3), pp. 4-12.

--- (2019) Literature: Why it Matters. Cambridge: Polity.

Farmelo, G. (2002) It Must Be Beautiful: Great Equations of Modern Science. London: Granta.

Fielding, M. (2005) 'Alex Bloom, Pioneer of Radical State Education,' Forum 27(2\&3), pp. 119-134.

--- (2014) Radical Democratic Education as Response to Two World Wars and a Contribution to World Peace: The Inspirational Work of Alex Bloom,' Forum 56(3), pp. 513-527.

Flood, A. (2018) 'Publisher Defends Diversity Drive after Lionel Shriver 's Attack.' Guardian. 11 June. Available online at: https://www.theguardian.com/books/2018/jun/11/publisher-defends-diversity-drive-afterlionel-shrivers-attack (accessed 29 January 2019).

Gibb, N. (2016) 'Nick Gibb: What is a Good Education in the $21^{\text {st }}$ Century?', Gov.UK. Available online at: https://www.gov.uk/government/speeches/what-is-a-good-education-in-the-21st-century (accessed 18 February 2017).

--- (2017) 'Nick Gibb: The importance of Knowledge-Based Education,' Gov.UK. Available online at: https://www.gov.uk/government/speeches/nick-gibb-the-importance-of-knowledge-based-education (accessed 25 November 2018).

--- (2018) 'Nick Gibb: How Can Policy Ensure Education Equity?', Gov.UK. Available online at: https://www.gov.uk/government/speeches/nick-gibb-how-can-policy-ensure-education-equity (accessed 25 November 2018).

Gordon, L.R. (1997), Existence in Black: An Anthology of Black Existential Pbilosophy. New York: Routledge.

Gov.UK(a) (n.d.) 'The National Curriculum.' Available online at: https://www.gov.uk/national-curriculum (accessed 25 November 2018). 
--- (b) (n.d.) 'Types of School.' Available online at: https://www.gov.uk/types-of-school (accessed 25 November 2018).

Gove, M. (2013a) 'What does it Mean to be an Educated Person?', Gov.UK. Available online at: https://www.gov.uk/government/speeches/what-does-it-mean-to-be-an-educated-person (accessed 03 June 2018).

--- (2013b) 'Michael Gove Speaks about the Importance of Teaching,' Gov.UK. Available online at: https://www.gov.uk/government/speeches/michael-gove-speaks-about-the-importance-of-teaching (accessed 25 November 2018).

--- (2014) 'Michael Gove Speaks about the Future of Education Reform,' Gov.UK. Available online at: https://www.gov.uk/government/speeches/michael-gove-speaks-about-the-future-of-education-reform (accessed 25 November 2018).

Greene, M. (2001) V ariations on a Blue Guitar: The Lincoln Center Institute Lectures on Aesthetic Education. New York: Teachers College Press.

Heidegger, M. (1975) Poetry, Language, Thought. Trans. Albert Hofstadter. New York: Harper Colophon.

Higgins, S. and Baumfield, V. (1998) 'A Defence of General Thinking Skills,' Journal of Philosophy of Education 32(3), pp. 391-398

Hinchliffe (2002) 'Situating Skills,' Journal of Philosophy of Education 36(2), pp. 187-205.

Huthcinson, G. (1995) The Harlem Renaissance in Black and White. Massachusetts: Belknap Press-Harvard University Press.

Inglis, F., and Aers, L. (2008) Key Concepts in Education. London: SAGE.

Johnson, S. and Gardner, P. (1999) 'Some Achilles' Heels of Thinking Skills: A Response to Higgins and Baumfield,' Journal of Philosophy of Education 33(3), pp. 435-449.

Levinson, M. (dir.) (2013) Particle Fever.

Locke, A (ed.) [1925] The New Negro: Voices of the Harlem Renaissance. New York: Touchstone, 1997.

Lorde, A. (2007) Sister Outsider: Essays and Speeches. Berkeley: Crossing Press.

Maracle, L. (1996) I Am Woman: Native Perspectives on Sociology and Feminism. Vancouver: Press Gang.

McCallum, A. (2019) 'Response to Ofsted Curriculum Workshop.' EMC. Available online at: https://www.englishandmedia.co.uk/blog/response-to-ofsted-curriculum-workshop (accessed 29 January 2019).

McDowell, J. (1994) Mind and World. Cambridge, MA: Harvard University Press.

--- (2013). 'The Myth of the Mind as Detached,' in Schear (2013), pp. 41-58.

Merleau-Ponty, M. (1973) The Prose of the World. Trans. John O’Neill. Evanston: Northwestern University Press.

Penguin Random House [PRH] (n.d.) Creative Responsibility: Inclusion. [Webpage.] Available online at: https://www.penguin.co.uk/company/creative-responsibility/Inclusion.html (accessed 29 January 2019).

QAA (2016) Subject Benchmark Statement: Creative Writing. QAA. Available online at: https://www.qaa.ac.uk/docs/qaa/subject-benchmark-statements/sbs-creative-writing16.pdf?sfvrsn=d4e2f781 10 (accessed 29 January 2019).

Rancière, J. (2009) The Emancipated Spectator. Trans. Gregory Elliott. London: Verso.

Richards, I.A. [1924] Principles of Literary Criticism. London: Routledge, 1989.

Riesing, R. (1986) The Unusable Past: Theory and the Study of American Literature. London: Routledge.

Rose, S. (1997) Lifelines: Biology, Freedom, Determinism. London: Allen Lane-Penguin.

Ryle, G. [1949] The Concept of Mind. Abingdon: Routledge, 2009.

Schear, J.K. (ed.) (2013). Mind, Reason, and Being-In-The-World: The McDowell-Dreyfus Debate. London: Routledge.

Schrage, M. (2010) 'Higher Education is Overrated; Skills Aren't,' Harvard Business Review. Available online at: https://hbr.org/2010/07/higher-education-is-highly-ove.html (accessed 25 November 2018).

Tompkins, J.P. (1980) Reader-Response Criticism: From Formalism to Post-Structuralism. Baltimore: The Johns Hopkins University Press.

UCAS (2018) Apprenticeship of Fine Arts in Creative Writing. [Information page.] Available online at: https://qips.ucas.com/eip/apprentice-of-fine-arts-creative-writing-afa (accessed 29 January 2019).

The Writers' Examination Board [WEB]. About. [Webpage.] Available online at: https://writersexaminationboard.com/about/ (accessed 29 January 2019).

Winch, C., and Gingell, J. (1999) Key Concepts in the Philosopby of Education. London: Routledge.

Yancy, G. (2017) Black Bodies, White Gares: The Continuing Significance of Race in America. 2nd Ed. New York: Rowman 
and Littlefield.

Youdell, D. (2011) School Trouble: Identity, Power and Politics in Education. Oxon: Routledge.

Young, M., and Muller, J. (2013) 'On the Powers of Powerful Knowledge,' Review of Education 1(3), pp.229-250.

Zipin, L. (2017) 'Pursuing a Problematic-Based Curriculum Approach for the Sake of Social Justice,' Journal of Education 69, pp.67-92. 